\title{
Evaluation of Quinoxyfen Resistance of Erysiphe necator (Grape Powdery Mildew) in a Single Virginia Vineyard
}

Xuewen Feng, Department of Plant Pathology, Physiology and Weed Science, Virginia Tech, Blacksburg 24061; Mizuho Nita, Alson H. Smith Agricultural Research and Extension Center, Virginia Tech, 595 Laurel Grove Rd., Winchester, VA 22602 ; and Anton B. Baudoin, ${ }^{\dagger}$ School of Plant and Environmental Sciences, 417 Price Hall, Virginia Tech, Blacksburg 24061

\begin{abstract}
The protectant fungicide quinoxyfen has been used against grape powdery mildew (Erysiphe necator) in the United States since 2003. In 2013, isolates of grape powdery mildew with reduced quinoxyfen sensitivity (here designated as quinoxyfen lab resistance or QLR) were detected in a single vineyard in western Virginia, USA. Field trials were conducted in 2014, 2015, and 2016 at the affected vineyard to determine to what extent quinoxyfen might still contribute to disease control. Powdery mildew control by quinoxyfen was similar to, or only slightly less than, that provided by myclobutanil and boscalid in all three years. In 2016, early- versus late-season applications of quinoxyfen were compared to test the hypothesis that early-season applications were more effective, but differences were small. A treatment with two early

quinoxyfen applications, at bloom and 2 weeks later, followed by a myclobutanil-boscalid plus a low dose of sulfur rotation provided slightly better control of foliar disease incidence than treatments containing four quinoxyfen applications or two midseason or two late quinoxyfen applications supplemented by myclobutanil and boscalid applications; severity differences were small and nonsignificant. Metrafenone and benzovindiflupyr generally provided excellent powdery mildew control. The frequency of QLR in vines not treated with quinoxyfen slowly declined from $65 \%$ in 2014 to $46 \%$ in 2016 . Further research is needed to explain how, despite this QLR frequency, quinoxyfen applied to grapes in the field was still able to effectively control powdery mildew.
\end{abstract}

Erysiphe necator Schwein., the causal agent of grapevine powdery mildew, is a damaging pathogen widespread in all grape growing areas (Dhillon et al. 1992; Gadoury et al. 2012, 2015; Halleen and Holz 2001). Powdery mildew infections can lead to poor fruit set, premature fruit drop, berry cracking, increased acid concentration, and off-flavors of wines (Stummer et al. 2005). When berries crack, the ruptured diseased berries also have increased susceptibility to secondary infection by other pathogenic organisms such as Botrytis cinerea (Halleen and Holz 2001; Thind et al. 2004). The biology, epidemiology, and management of grapevine powdery mildew have been recently reviewed (Gadoury et al. 2015). In the western part of Virginia, USA, overwintering of the pathogen in buds appears to be uncommon or absent due to low winter temperatures, but chasmothecia are commonly observed as the source of overwintering inoculum (Gadoury et al. 2015).

Quinoxyfen (trade name: Quintec) is a surface-mobile protectant fungicide developed by Dow AgroSciences. It has specific activity against powdery mildews of a variety of crops, and has been available for use on grapes in the United States since 2003. Details of its mode of action are still somewhat uncertain, but, as with other single-site powdery-mildew fungicides, the potential for the development of resistance has been a concern. Laboratory mutants and field isolates of Blumeria graminis (barley powdery mildew) with reduced sensitivity to quinoxyfen were described by Hollomon et al. (1997) and Wheeler et al. (2003), but had reduced sporulation. Green and Duriatti (2005) documented the baseline sensitivity of grape powdery mildew and reported $\mathrm{EC}_{50}$ values ranging from 0.008 to $2.6 \mathrm{mg} / \mathrm{liter}$. Green and Gustafson (2006) used a discriminatory dose

${ }^{\dagger}$ Corresponding author: A. Baudoin; E-mail: abaudoin@vt.edu

Funding: We thank the Virginia Wine Board and the Dow Chemical Company for their financial support.

*The $\boldsymbol{e}$-Xtra logo stands for "electronic extra" and indicates that one supplementary table is published online.

Accepted for publication 5 June 2018.

(C) 2018 The American Phytopathological Society of $50 \mathrm{mg} /$ liter (within the field application rate of 25 to $120 \mathrm{mg} / \mathrm{liter}$ ) to select less-sensitive isolates of the grape powdery mildew pathogen, and detected isolates with $\mathrm{EC}_{50}$ above $30 \mathrm{mg} / \mathrm{liter}$. Six years after the commercialization of quinoxyfen, grape powdery mildew field isolates with high quinoxyfen resistance ( $\mathrm{EC}_{50}$ up to nearly $100 \mathrm{mg} / \mathrm{liter}$ ) were reported in Europe (Genet and Jaworska 2009). "Strongly adapted" isolates have been discovered annually in Europe since then (Kemmitt et al. 2017). The 2016 annual meeting minutes of the azanaphthalene (AZN) working group of the Fungicide Resistance Action Committee (FRAC) indicated that "adapted isolates able to grow actively at a discriminatory dose of either proquinazid or quinoxyfen which controls baseline isolates have been detected across Europe" (Kemmitt et al. 2017). The frequency and the degree of adaptation of these isolates varied significantly between monitored regions within countries and also from year to year over the period of monitoring from 2003 to 2016 (Kemmitt et al. 2017). However, implications for disease control in the field appear to have not been reported beyond the annual meeting minutes of the FRAC AZN working group. The 2011 AZN working group minutes (no longer available online) included the statement "Field performance is not affected when the products have been used according to label recommendations. There were no field performance issues to proquinazid or quinoxyfen", but this statement was omitted from the minutes of subsequent years (Kemmitt et al. 2013, 2014, 2017). Field trials in western New York conducted during 2010 and 2011 revealed reduced control of grape powdery mildew by quinoxyfen, which was attributed to "hypothesized, but not confirmed resistance" (Wilcox and Riegel 2012a, 2012b, 2012c).

In September 2013, difficulties with powdery mildew control in a commercial vineyard in western Virginia were reported by the grower. The grower had applied quinoxyfen as a major component of the powdery mildew management program in certain blocks for eight consecutive years, with four applications in each of the most recent three seasons. The powdery mildew isolates collected at this site grew well on both detached leaves and potted plants treated with full label rates (3 to 6.6 fluid oz./acre, equivalent to 60 to $130 \mathrm{mg}$ a.i./liter if applied at 100 gal./acre or 935 liters/ha) (Colcol and Baudoin 2016). Such isolates appeared to be present at high frequency, and had not previously been observed in Virginia.

To test the hypothesis that efficacy of quinoxyfen would be reduced in the affected vineyard, we conducted studies from 2014 to 
2016 to determine: (1) the frequency of quinoxyfen resistance in the grape powdery mildew pathogen population in the affected area of Virginia; (2) the extent to which the field efficacy of quinoxyfen against grape powdery mildew was reduced; and (3) whether the number of applications and the application timing would affect the degree of control.

\section{Materials and Methods}

Field trials. In our current study, since we found only a slight loss of efficacy of quinoxyfen in the field, we will refer to our isolates with reduced sensitivity in the lab, as described by Colcol and Baudoin (2016), as "quinoxyfen lab resistant" or QLR isolates.

Field trials were conducted in three separate seasons at the western Virginia vineyard (hereafter referred to as "QLR vineyard") where QLR grape powdery mildew isolates had been collected in the fall of 2013 (Colcol and Baudoin 2016). In 2014, a trial was set up in two rows of 'Chambourcin' grapes (a French-American hybrid, planted in 1996, own-rooted, multitrunked, modified Smart-Dyson "Ballerina" trained, part of the block where 2013 powdery mildew control had been inadequate) with plots consisting of four vines. The trial included five treatments (Table 1), each replicated four times. The grower spray program from budbreak through prebloom consisted of mancozeb and sulfur, and trial applications were initiated at bloom. A five-spray quinoxyfen (Quintec, Dow AgroSciences, $73 \mathrm{~g}$ a.i./ha) program was compared with a boscalid (221 $\mathrm{g}$ a.i./ha, Endura, BASF Corporation, Research Triangle Park, NC)-myclobutanil (84 g a.i./ha, Rally, Dow AgroSciences) rotation supplemented with a low dose of sulfur (897 g a.i./ha, Microthiol Disperss, UPI, King of Prussia, PA), and also compared with metrafenone (224 g a.i./ha, Vivando, BASF Corporation). A treatment of quinoxyfen plus boscalid/myclobutanil+sulfur was included to determine whether quinoxyfen might still add efficacy to a partially effective treatment. Treatments of all plots (including the controls where no antipowdery mildew fungicide was applied) were supplemented with $0.3 \%$ Prophyt (potassium phosphite, $54.5 \%$ active ingredient, Helena Chemical Company, Collierville, TN) and mancozeb (841 g a.i./ha, Dithane 75DF Rainshield, Dow AgroSciences) at early applications, or, at later applications, Prophyt plus azoxystrobin (179 g a.i./ha, Abound, Syngenta Crop Protection, Greensboro, NC) for control of downy mildew (Prophyt) and/or black rot (azoxystrobin; powdery and downy mildew at this location were QoI resistant). Application volume of the first two sprays was 650 liters/ha, of the remainder 750 liters/ha. Nine days after the first trial spray, two of the blocks were mistakenly treated by the vineyard manager with boscalid plus sulfur. In order to compensate, the remaining blocks were sprayed 5 days later with the same mixture, and trial sprays were resumed 13 days later.

Severity of powdery mildew on grape clusters was visually evaluated on 29 July, before berries started to change color, which makes it increasingly difficult to evaluate powdery mildew cluster infection; two evaluators each rated 15 randomly chosen clusters on each side of each plot ( 60 clusters per plot) by estimating the percentage of the surface covered by visible powdery mildew. The last treatment application was made on 16 August, and foliar disease severity was rated on 14 September, by counting powdery mildew colonies on mature leaves per 2-min search for each side of every plot. This method was used because the disease level was low and a much larger portion of the foliage could be inspected in the time available than with leafby-leaf assessments. Similar rating methods, as well as severity assessments on randomly chosen mature leaves, were used in 2015 and 2016 and are specified in Tables 2 and 3.

In 2015, two parallel field trials were conducted at the same vineyard. One trial was set up in two rows of the same Chambourcin block as in 2014 with plots consisting of four vines; the other was set up in a row of Pinot noir ( $V$. vinifera, planted in 1995, on Couderc 3309 rootstock, open-lyre trained) approximately $200 \mathrm{~m}$ distant from the Chambourcin plots with four or five vines per plot (Table 2). Each trial consisted of the same five treatments, five applications, and four replicates, and the same application volumes as in 2014. The grower spray program from budbreak through prebloom consisted of mancozeb and sulfur. Treatment applications were supplemented with Prophyt $(0.4 \%)$ and mancozeb (841 g a.i./ha) at early applications or Prophyt plus azoxystrobin (179 $\mathrm{g}$ a.i./ha) at later applications for control of downy mildew and black rot. In 2014 and 2015, applications were made with a Solo (Solo USA, Newport News, VA) model 410 backpack mistblower with wide-spray nozzle and deflector screen.

In 2016, the field trial was set up in two rows of Pinot noir with plots consisting of four or five vines, and treatments were applied with a Jacto (Jacto Inc., Tualatin, OR) XP416 backpack sprayer with a TeeJet 8003VS XR nozzle (TeeJet, Glendale Heights, IL). Six fungicide treatments, plus an untreated control, were compared (Table 3), each replicated four times and receiving six applications during the season, at the same application volumes as in previous years. One added treatment was benzovindiflupyr (Aprovia, Syngenta, $63 \mathrm{~g}$ a.i./ha), a new powdery mildew fungicide registered in the United States in 2015. Four treatments included quinoxyfen rotated with myclobutanil+sulfur and boscalid+sulfur; these treatments varied in number and timing of quinoxyfen applications. The prebloom grower spray program consisted of mancozeb and sulfur, as in 2014 and 2015. Trial applications included Prophyt (0.5\%), mandipropamid (Revus, 146 $\mathrm{g}$ a.i./ha, Syngenta), mancozeb (841 g a.i./ha), or captan (1.12 $\mathrm{kg}$ a.i./ha, Captan 80WDG, Albaugh, Inc., Ankeny, IA) for control of downy mildew. Azoxystrobin (179 g a.i./ha) was included in the first three applications of all treatments for control of black rot.

Statistical analyses. Data analyses were conducted in $\mathrm{R}$ ver. 3.4.4 ( $\mathrm{R}$ Core Team 2017). Generalized linear mixed models (GLMM) were used to analyze the effect of the treatments on powdery mildew disease incidence (as the probability of detecting infected clusters) and colony count, using the binomial and Poisson distribution, respectively. Models were fitted using the glmer function of the

Table 1. Powdery mildew severity on grape clusters and leaves, Chambourcin, 2014

\begin{tabular}{|c|c|c|c|}
\hline \multirow[b]{2}{*}{ Treatment and application sequence ${ }^{x}$} & \multicolumn{2}{|c|}{29 July } & \multirow{2}{*}{$\begin{array}{c}14 \text { September } \\
\text { Foliary colonies } / 2 \text { min } \\
\left(X^{2}=777, P<0.001\right)\end{array}$} \\
\hline & $\begin{array}{c}\text { Cluster }{ }^{\mathrm{y}} \text { severity \% } \\
(F=75, P<0.001)\end{array}$ & $\begin{array}{c}\text { Clustery }^{\mathrm{y}} \text { incidence } \\
\left(X^{2}=165, P<0.001\right)\end{array}$ & \\
\hline Nontreated control & $14.8 \mathrm{a}^{\mathrm{z}}$ & $0.77 \mathrm{a}^{\mathrm{z}}$ & $83.1 \mathrm{a}^{\mathrm{z}}$ \\
\hline $\mathrm{Q}, \mathrm{Q}, \mathrm{Q}, \mathrm{Q}, \mathrm{Q}$ & $0.2 \mathrm{~b}$ & $0.17 \mathrm{~d}$ & $6.6 \mathrm{~b}$ \\
\hline $\mathrm{B}+\mathrm{S}, \mathrm{B}+\mathrm{S}, \mathrm{M}+\mathrm{S}, \mathrm{M}+\mathrm{S}, \mathrm{B}+\mathrm{S}$ & $1.7 \mathrm{~b}$ & $0.30 \mathrm{c}$ & $3.3 \mathrm{c}$ \\
\hline Mf, Mf, Mf, Mf, Mf & $2.4 \mathrm{~b}$ & $0.44 \mathrm{~b}$ & $0.4 \mathrm{~d}$ \\
\hline $\mathrm{Q}+\mathrm{B}+\mathrm{S}, \mathrm{Q}+\mathrm{B}+\mathrm{S}, \mathrm{Q}+\mathrm{M}+\mathrm{S}, \mathrm{Q}+\mathrm{M}+\mathrm{S}, \mathrm{Q}+\mathrm{B}+\mathrm{S}$ & $0.9 \mathrm{~b}$ & $0.35 \mathrm{bc}$ & $1.3 \mathrm{~cd}$ \\
\hline
\end{tabular}

${ }^{\mathrm{x}} \mathrm{Q}=$ quinoxyfen, $73 \mathrm{~g}$ a.i./ha. $\mathrm{B}=$ boscalid, $221 \mathrm{~g}$ a.i./ha. $\mathrm{S}=$ sulfur, $897 \mathrm{~g}$ a.i./ha. $\mathrm{M}=$ myclobutanil, $84 \mathrm{~g}$ a.i./ha. $\mathrm{Mf}=$ metrafenone, $224 \mathrm{~g}$ a.i./ha. Applications were carried out on 12 June (60\% bloom), 12 June (60\% caps off), 26 June, 9 July, 23 July (berries beginning to color and enlarge), and 16 August. Antidowny and -black rot materials were applied to all treatments, and sulfur, $897 \mathrm{~g}$ a.i./ha, was applied to all plots on 7 August. All plots, including the nontreated control, received a treatment with boscalid+sulfur between the second and the third spray.

${ }^{y}$ Cluster severity: percent of surface area covered by powdery mildew, estimated for 30 clusters per plot evaluated separately by each of two evaluators. Cluster incidence: proportion of diseased clusters per plot. Foliar colonies: number of powdery mildew colonies on leaves per 2-min search for each side of each plot.

${ }^{\mathrm{z}}$ Powdery mildew disease incidence and colony count were analyzed with generalized linear mixed models (GLMM). Linear mixed models (LMM) was used to analyze the effect of the treatments on powdery mildew disease severity. Data in a column with the same letter are not significantly different $(P=0.05)$. 
"Ime4" R package. Disease incidence data assessed on 23 Aug 2015 suffered from a "separation" or "monotone likelihood" issue (Heinze and Schemper 2002) where one of the levels of a fixed effect fully explains the binomial response variable (e.g., one of the treatments resulted in all zero values). A GLMM converged, but one of the standard error estimates diverged to a very high number. In order to overcome this issue, the bglmer function of an R package "blme" was used. This Bayesian approach uses the algorithm similar to that of the "Ime4", and allows a user to add a weak prior probability to assist the estimation of parameters. Linear mixed models (LMM) with an assumption of the normal distribution of data were used to analyze the effect of the treatments on powdery mildew disease severity. For all models, the treatment factor was considered as a fixed effect and the block factor was considered as a random effect. When there were two raters involved in the assessment, we considered both block and rater factors as random effects. Once the treatment factor was found to be significant $(P \leq 0.05)$, Tukey post hoc tests with a family-wise error rate of 0.05 were performed with the glht function of the "multcomp" $\mathrm{R}$ package.

Isolate collection and maintenance. Isolates were collected from the QLR vineyard during the 2014 to 2016 growing seasons, and from two nearby locations, one about $8 \mathrm{~km}$ to the west, the other one about $16 \mathrm{~km}$ to the northeast of the QLR vineyard. Since those vineyards, due to their spray program, were not expected to reliably experience powdery mildew outbreaks, four "sentinel" Chardonnay vines in 13-liter pots were stationed at each of these locations; two of them were sprayed weekly with $10 \mathrm{mg}$ a.i./liter quinoxyfen and the remainder were nontreated controls. These plants were visited approximately every 14 days, and powdery mildew was collected as disease developed. Infected leaves were collected throughout the season whenever apparently active powdery mildew was seen, and were brought to the lab in Ziploc bags, with leaves from quinoxyfentreated plots and nontreated areas kept separate. Isolates obtained from such leaves were maintained and bioassayed on young greenhousegrown leaves collected from positions 3 to 5 from the tip of the shoot of susceptible Vitis vinifera 'Chardonnay' as described previously (Colcol and Baudoin 2016). These leaves were surface-disinfested by immersing in a $20 \%$ bleach solution with Tween 20 ( 1 or 2 drops per $100 \mathrm{ml}$ bleach solution) for $2 \mathrm{~min}$, then blotted with paper towel in a laminar-flow hood and placed on $1 \%$ water agar with sterile utensils. The leaves were inoculated by gently rubbing diseased field leaves (within a few days after collection) on them, and were incubated for 7 to 10 days at room temperature $\left(22\right.$ to $\left.26^{\circ} \mathrm{C}\right)$ to allow sporulating colonies to develop. Under a dissecting microscope, single chains of conidia were transferred individually from the developed colonies to surface-disinfested leaves using acupuncture needles, and the plates with those leaves were incubated for 7 to 10 days. Conidia from these subcultures were used in bioassay to test the sensitivity of E. necator isolates.

Bioassay. Since quinoxyfen dose has little effect on inhibition of QLR isolates (Colcol and Baudoin 2016; Lee et al. 2008; Wheeler et al. 2000, 2003) and based on previous results (Colcol and Baudoin 2016), a discriminatory concentration of $30 \mathrm{mg} / \mathrm{liter}$ was used in this study. The reaction of an isolate was usually clear: on leaf tissue

Table 2. Powdery mildew severity on clusters and leaves, Pinot noir, 2015

\begin{tabular}{|c|c|c|c|c|c|}
\hline \multirow[b]{2}{*}{$\begin{array}{l}\text { Treatment and application } \\
\text { sequence }^{x}\end{array}$} & \multicolumn{2}{|c|}{14 July } & \multirow{2}{*}{$\begin{array}{c}\frac{12 \text { August }}{\text { Foliar colonies } / 4 \min ^{\mathrm{x}}} \\
\left(X^{2}=950, P<0.001\right)\end{array}$} & \multicolumn{2}{|c|}{23 August } \\
\hline & $\begin{array}{r}\text { Clustery severity, \% } \\
(F=99, P<0.001)\end{array}$ & $\begin{array}{c}\text { Clustery incidence } \\
\left(X^{2}=241, P<0.001\right)\end{array}$ & & $\begin{array}{l}\text { Foliary }^{\mathrm{y}} \text { severity, \% } \\
(F=43, P<0.001)\end{array}$ & $\begin{array}{c}\text { Foliar }^{\mathrm{y}} \text { incidence } \\
\left(X^{2}=134, P<0.001\right)\end{array}$ \\
\hline Nontreated control & $10.8 \mathrm{a}^{\mathrm{z}}$ & $0.74 \mathrm{a}^{\mathrm{z}}$ & $139.5 \mathrm{a}^{\mathrm{z}}$ & $5.3 \mathrm{a}^{\mathrm{z}}$ & $0.38 \mathrm{a}^{\mathrm{z}}$ \\
\hline $\mathrm{Q}, \mathrm{Q}, \mathrm{Q}, \mathrm{Q}, \mathrm{Q}$ & $1.7 \mathrm{~b}$ & $0.23 \mathrm{c}$ & $55.6 \mathrm{~b}$ & $2.9 \mathrm{~b}$ & $0.23 \mathrm{~b}$ \\
\hline $\mathrm{B}+\mathrm{S}, \mathrm{B}+\mathrm{S}, \mathrm{M}+\mathrm{S}, \mathrm{M}+\mathrm{S}, \mathrm{B}+\mathrm{S}$ & $1.1 \mathrm{~b}$ & $0.35 \mathrm{~b}$ & $3.1 \mathrm{c}$ & $0.1 \mathrm{c}$ & $0.03 \mathrm{c}$ \\
\hline $\begin{array}{c}\mathrm{Q}+\mathrm{B}+\mathrm{S}, \mathrm{Q}+\mathrm{B}+\mathrm{S}, \mathrm{Q}+\mathrm{M}+\mathrm{S} \\
\mathrm{Q}+\mathrm{M}+\mathrm{S}, \mathrm{Q}+\mathrm{B}+\mathrm{S}\end{array}$ & $0.5 \mathrm{~b}$ & $0.16 \mathrm{c}$ & $4.0 \mathrm{c}$ & $0.1 \mathrm{c}$ & $0.01 \mathrm{c}$ \\
\hline Mf, Mf, Mf, Mf, Mf & $0.1 \mathrm{~b}$ & $0.03 \mathrm{~d}$ & $0.1 \mathrm{~d}$ & $0.0 \mathrm{c}$ & $0 \mathrm{c}$ \\
\hline
\end{tabular}

x Rates as in Table 1. Applications were carried out on 2 June (10\% caps off), 15 June, 29 June (berries pea-size), 14 July (berries touching), and 28 July (veraison)

${ }^{y}$ Cluster disease severity: 30 clusters per plot evaluated separately by each of two evaluators. Cluster incidence is the proportion of diseased clusters. Foliar colonies were counted in a 2-min search by two evaluators, one on each side of the row. Foliar disease severity as percent of leaf surface, 65 leaves evaluated per plot. Foliar incidence is the proportion of leaves infected.

${ }^{\mathrm{z}}$ Powdery mildew disease incidence and colony count were analyzed with generalized linear mixed models (GLMM). Linear mixed models (LMM) was used to analyze the effect of the treatments on powdery mildew disease severity. Data in a column with the same letter are not significantly different $(P=0.05)$.

Table 3. Powdery mildew severity on clusters and leaves, Pinot noir, 2016

\begin{tabular}{|c|c|c|c|c|c|c|c|c|}
\hline & & & \multicolumn{2}{|c|}{14 July } & \multicolumn{2}{|c|}{20 July } & \multicolumn{2}{|c|}{3 September } \\
\hline \multicolumn{3}{|c|}{ Treatments } & $\begin{array}{l}\text { Cluster } \\
\text { severity, }\end{array}$ & $\begin{array}{l}\text { Cluster }^{\mathbf{y}} \\
\text { incidence }\end{array}$ & $\begin{array}{l}\text { Cluster } \\
\text { severity, }\end{array}$ & $\begin{array}{c}\text { Cluster } \\
\text { incidence }\end{array}$ & $\begin{array}{c}\text { Foliar }^{\mathbf{y}} \\
\text { severity, }\end{array}$ & $\begin{array}{c}\text { Foliary }^{\mathbf{y}} \\
\text { incidence }\end{array}$ \\
\hline $\operatorname{Code}^{x}$ & Before 20 July $^{x}$ & After 20 July $^{x}$ & $P<0.001)$ & $P<0.001)$ & $P<0.001)$ & $P<0.001)$ & $P<0.001)$ & $P<0.001)$ \\
\hline $\mathrm{C}$ & Control & Control & $1.4 \mathrm{a}^{\mathrm{z}}$ & $0.25 \mathrm{a}^{\mathrm{z}}$ & $9.6 \mathrm{a}^{\mathrm{z}}$ & $0.81 \mathrm{a}^{\mathrm{z}}$ & $37.0 \mathrm{a}^{\mathrm{z}}$ & $0.91 \mathrm{a}^{\mathrm{z}}$ \\
\hline $4 \mathrm{Q}$ & $\mathrm{Q}, \mathrm{Q}, \mathrm{Q}$ & $\mathrm{Q}, \mathrm{M}+\mathrm{S}, \mathrm{B}+\mathrm{S}$ & $0.2 \mathrm{~b}$ & $0.07 \mathrm{~b}$ & $2.0 \mathrm{bc}$ & $0.45 \mathrm{~b}$ & $1.6 \mathrm{~b}$ & $0.19 \mathrm{~b}$ \\
\hline $2 \mathrm{QL}$ & $\mathrm{M}+\mathrm{S}, \mathrm{B}+\mathrm{S}, \mathrm{M}+\mathrm{S}$ & $\mathrm{B}+\mathrm{S}, \mathrm{Q}, \mathrm{Q}$ & - & & $0.7 \mathrm{c}$ & $0.22 \mathrm{c}$ & $1.4 \mathrm{~b}$ & $0.22 \mathrm{~b}$ \\
\hline 2QM & $\mathrm{M}+\mathrm{S}, \mathrm{B}+\mathrm{S}, \mathrm{Q}$ & $\mathrm{Q}, \mathrm{M}+\mathrm{S}, \mathrm{B}+\mathrm{S}$ & - & & - & - & $0.5 \mathrm{~b}$ & $0.12 \mathrm{c}$ \\
\hline $2 \mathrm{QE}$ & $\mathrm{Q}, \mathrm{Q}, \mathrm{M}+\mathrm{S}$ & $\mathrm{B}+\mathrm{S}, \mathrm{M}+\mathrm{S}, \mathrm{B}+\mathrm{S}$ & - & & - & - & $0.1 \mathrm{~b}$ & $0.03 \mathrm{~d}$ \\
\hline Mf & Mf, Mf, Mf & Mf, Mf, Mf & $0 \mathrm{~b}$ & $0.02 \mathrm{c}$ & $0.1 \mathrm{~b}$ & $0.06 \mathrm{~d}$ & $0 \mathrm{~b}$ & $0 \mathrm{~d}$ \\
\hline $\mathrm{Bv}$ & $\mathrm{Bv}, \mathrm{Bv}, \mathrm{Bv}$ & $\mathrm{Bv}, \mathrm{Bv}, \mathrm{Bv}$ & $0.1 \mathrm{~b}$ & $0.02 \mathrm{c}$ & - & - & $0 \mathrm{~b}$ & $0 \mathrm{~d}$ \\
\hline
\end{tabular}

${ }^{\mathrm{x}}$ Rates and abbreviations as in Table 1, Bv = benzovindiflupyr, $63 \mathrm{~g}$ a.i./ha. Applications were carried out on 9 June (40\% caps off), 22 June (berries pepper-corn size), 6 July (berry touching), 20 July (berries beginning to color and enlarge), 5 August, and 19 August. The three applications before 20 July are listed separately from the applications after 20 July, as the cluster ratings were performed after the first three applications, while the leaf rating was performed after all six applications.

y Cluster severity based on 50 clusters per plot (14 July, 8 days after the third antipowdery mildew spray) or 40 clusters per plot ( 20 July 2016 , 14 days after the third antipowdery mildew spray); Cluster incidence is the proportion of diseased clusters. Foliar severity based on 60 leaves per plot, rated 15 days after the fifth antipowdery mildew spray. Data for $4 \mathrm{Q}$ are the average of three sets of treatments that differed in downy mildew treatment; data for $2 \mathrm{QM}$ the average of two treatments. Foliar incidence as the proportion of leaves infected.

${ }^{\mathrm{z}}$ Powdery mildew disease incidence and colony count were analyzed with generalized linear mixed models (GLMM). Linear mixed models (LMM) was used to analyze the effect of the treatments on powdery mildew disease severity. Data in a column with the same letter are not significantly different $(P=0.05)$. 
treated with $10 \mathrm{mg} /$ liter or higher, the isolate either grew well (QLR), or did not grow at all or grew very little (sensitive). Formulated quinoxyfen used in biological assay was provided by Dow AgroSciences LLC. Surface-disinfested young grape leaves as described above were cut into strips of approximately $15 \times 40 \mathrm{~mm}$, the leaf pieces were randomized, and immersed in either sterile water (control) or quinoxyfen suspension of $30 \mathrm{mg} /$ liter for $45 \mathrm{~min}$. They were then gently blotted with a clean paper towel in a laminar-flow hood and plated onto $1 \%$ water agar using sterile utensils, three strips per plate. Nontreated and quinoxyfen-treated leaf pieces in separate plates were inoculated with conidia from one single-spored subculture, at four locations per leaf piece. The inoculated cultures were incubated for 7 to 10 days at room temperature $\left(25^{\circ} \mathrm{C}\right)$ under fluorescent lights with a 14-h photoperiod. The number of colonies in each plate was recorded. Single-spored isolates producing more than three colonies from 12 inoculation points on quinoxyfen-treated leaf tissue while producing more than six colonies growing on nontreated leaf tissue were categorized as "QLR" isolates; isolates producing no colonies on quinoxyfen-treated tissue while producing more than six colonies on nontreated tissue were considered "sensitive"; usually, the number of colonies was either high or zero, and borderline responses or tests with fewer than six colonies on untreated leaves were followed by a retest.

\section{Results}

The effect of treatment on powdery mildew measurement (severity, incidence, or colony count) was significant in all years and cultivars examined (Tables $1-3$ ). Powdery mildew severity was fairly low in the 2014 field trial. In contrast with laboratory results with leaf discs or potted plants (Colcol and Baudoin 2016), quinoxyfen provided very good powdery mildew control in the field, and was as effective (cluster severity $29 \mathrm{Jul}$ ), more effective (cluster incidence 29 Jul), or almost as effective (foliar evaluation 14 Sep) as the other fungicide treatments (Table 1). The treatment comprised of quinoxyfen alone provided $99 \%$ control of cluster disease severity and $92 \%$ control of foliar symptoms, whereas the other treatments provided 89 to $94 \%$ control of cluster disease and 96 to $100 \%$ control of foliar infection.

In 2015, little powdery mildew developed in the Chambourcin plots until late in the season. No powdery mildew was detected on 28 July, 15 days after the third application, and only one cluster with a very small amount of infection was seen on 12 August. Some foliar infection developed later, and the 5 September rating, 53 days after the last application, revealed low disease levels (treatment and control means were all below $0.4 \%$ of the leaf surface) and no statistically significant treatment differences (data not shown).

Both cluster and foliar powdery mildew symptoms developed in the 2015 Pinot noir trial (Table 2). At the 14 July cluster rating, after three treatment applications, quinoxyfen ( $84 \%$ control), boscalid/ myclobutanil rotation plus sulfur (90\% control), and quinoxyfen plus boscalid/myclobutanil rotation plus sulfur (95\% control) treatments still provided statistically indistinguishable control of disease severity, although there were slight differences in disease incidence, with metrafenone providing the best control. A foliar rating on 12 August, 15 days after the fifth application, revealed distinctly more powdery mildew in the quinoxyfen plots $(60 \%$ control of foliar colony numbers) than in the other treatments (97 to $98 \%$ control for treatments including boscalid), and all were different from the nontreated control. On 23 August, 25 days after the last application, control of foliar severity by quinoxyfen was only $45 \%$, whereas metrafenone and the boscalid/myclobutanil rotation plus sulfur treatments still had minimal disease levels at that time.

In 2016, at the cluster ratings on 14 and 20 July (Table 3) after three treatment applications, efficacy of the treatment comprised of quinoxyfen (4Q) was statistically the same as the other fungicide treatments with respect to severity, but significantly less when expressed as disease incidence. At the foliar rating on 3 September (Table 3), 15 days after the sixth application, all fungicide treatments provided statistically indistinguishable control of disease severity, but in the analysis of disease incidence, metrafenone and benzovindiflupyr performed significantly better than most of the quinoxyfen-containing treatments, except that two early (starting at bloom) quinoxyfen applications (2QE) provided control equivalent to metrafenone and benzovindiflupyr, and better than two midseason (2QM) and two late-season (2QL) quinoxyfen applications where the other applications were replaced by a myclobutanil/boscalid alternation plus sulfur. Treatments with four quinoxyfen applications (4Q) provided significantly less control of foliar incidence than treatments with two early-season quinoxyfen applications.

To determine QLR frequency, powdery mildew isolates were collected in this vineyard in each of the three seasons. The number of single-spored isolates from quinoxyfen-treated plots in 2014 was too small to allow conclusions, but the data from 2015 and 2016 indicate that a regular quinoxyfen application increased the frequency of the quinoxyfen QLR, as would be expected (Table 4). The QLR frequency in untreated areas of the vineyard slowly declined from $65 \%$ in 2014 to $46 \%$ in 2016.

A very limited number of powdery mildew colonies developed on the quinoxyfen-treated plants at the two other locations, whereas powdery mildew became moderately severe (northeast location) to severe (west location) on nontreated plants (no formal ratings were conducted). At the northeast location, 5 out of 31 isolates tested, or $16 \%$, were able to grow on quinoxyfen-treated leaves; at the west location, 2 of 42 isolates tested, or 5\%, were QLR. Surprisingly, isolates with reduced sensitivity appeared to be equally or more likely to be collected from nontreated (6 QLR isolates out of 51 total) than from quinoxyfen-treated plants (1 QLR isolate out of 22).

\section{Discussion}

Fungicide resistance has been of growing concern in grape powdery mildew management in many grape production regions. E. necator has developed resistance to a series of major fungicide groups (e.g., Colcol and Baudoin 2016), which seriously limits growers' management options and puts increased selection pressure on modes of action not yet affected by resistance. Although quinoxyfen resistance ("strongly adapted isolates") has been known in several European countries for over a decade, we could find no published data documenting their impact on disease management.

E. necator isolates with QLR were previously found to keep their QLR when maintained in the laboratory on treated as well as untreated leaves (Colcol and Baudoin 2016), and this was confirmed by maintaining single-spored isolates for another 10-12 generations (14 days per generation) and bioassaying them every two to three generations (data not shown). In the field, in competition with sensitive isolates, the QLR frequency in nontreated grapevines in the affected vineyard slowly declined from $65 \%$ in 2014 to $46 \%$ by 2016 . Some of this decline may be due to immigration from nontreated vineyards or wild grapevines, and the slow decline suggests at most a slight fitness penalty in the absence of selection by fungicide.

Due to the presence of a 46 to $65 \%$ frequency of isolates that could grow and sporulate on leaves and plants treated with field rates of quinoxyfen (Colcol and Baudoin 2016), we expected a substantial impact on quinoxyfen's efficacy. However, our field-test results showed only a slightly lower efficacy of quinoxyfen when compared with fungicides such as myclobutanil, boscalid, and metrafenone. In

Table 4. Average QLR frequencies in nontreated areas and quinoxyfen-treated plots of the quinoxyfen-resistance-affected vineyard, 2014-2016

\begin{tabular}{|c|c|c|c|}
\hline & \multicolumn{3}{|c|}{ QLR frequency ${ }^{z}$} \\
\hline & 2014 & 2015 & 2016 \\
\hline Untreated vines & $65 \%(n=124)$ & $50 \%(n=224)$ & $46 \%(n=100)$ \\
\hline Quinoxyfen-treated plots & $50 \%(n=18)$ & $81 \%(n=170)$ & $86 \%(n=99)$ \\
\hline \multicolumn{4}{|c|}{$\begin{array}{l}\text { z Isolates were collected throughout the growing seasons, single-spored, and } \\
\text { tested for ability to grow on grape leaf tissue treated with quinoxyfen at } \\
30 \mathrm{mg} / \text { /iter. Isolates producing more than three colonies from } 12 \text { inoculation } \\
\text { points on quinoxyfen-treated leaf tissue while producing more than six col- } \\
\text { onies growing on nontreated leaf tissue were categorized as "QLR" isolates; } \\
\text { isolates producing no colonies on quinoxyfen-treated tissue while producing } \\
\text { more than six colonies on nontreated tissue were considered "sensitive". }\end{array}$} \\
\hline
\end{tabular}


all three years, quinoxyfen provided cluster protection as effective or almost as effective as the other treatments, but its efficacy against foliar infection observed late in the season was weaker, especially in 2015. The relatively poor performance of metrafenone against cluster disease in 2014 was mostly due to a high rating in a single block where a disease focus was present, probably due to infection having become established during bloom before the first spray. In the 2014 foliar disease rating, and all 2015 and 2016 ratings, metrafenone provided near-complete control. In the 2016 field test, treatments that included four quinoxyfen applications and treatments that included two mid- or late-season quinoxyfen applications provided only slightly reduced control of foliar incidence compared with treatment $2 \mathrm{QE}$ with two early-season quinoxyfen applications, but all treatments provided good and statistically indistinguishable levels of control of foliar severity (Table 3).

The AZN Working Group of the Fungicide Resistance Action Committee (FRAC) has monitored for quinoxyfen resistance annually since 2003, and slightly to strongly adapted isolates have been widely found in Europe since 2006. The AZN Working Group has not reported any performance issues in the areas where the adapted isolates were discovered, but it is unclear to what extent this judgment is based on replicated field trials, and/or whether efficacy may have been due to mixing and rotating with other modes of action, as required or recommended by the label. Reports of reduced efficacy attributed to "hypothesized but not confirmed resistance" in field trials conducted in New York state in two consecutive years (2010 and 2011) did not characterize the powdery mildew population present. A quinoxyfen solo spray program provided good control of disease severity on clusters but only modest control of leaf disease severity and showed no control of disease incidence on either tissue (Wilcox and Riegel 2012a, 2012b, 2012c). This is somewhat similar to our field data, most clearly those from 2015 .

Green and Duriatti (2005) and Green and Gustafson (2006) documented baseline sensitivity of 56 unexposed E. necator isolates shortly after quinoxyfen had been put into the market, and reported an $\mathrm{EC}_{50}$ range of 0.008 to $2.6 \mathrm{mg} / \mathrm{liter}$. E. necator isolates with considerably reduced sensitivity $\left(\mathrm{EC}_{50}>2.6 \mathrm{mg} / \mathrm{liter}\right.$, approximately 10 to near $100 \mathrm{mg} / \mathrm{liter}$ ) have been discovered across Europe (Genet and Jaworska 2009; Green and Gustafson 2006), with variable frequencies (Kemmitt et al. 2017), but no specific frequency data were provided. Colcol and Baudoin tested 160 E. necator isolates sampled from Virginia and nearby states against quinoxyfen, and all the isolates were sensitive; the tested isolates all showed strongly reduced or no growth on leaf tissue treated with concentrations of 0.3 or $3 \mathrm{mg} / \mathrm{liter}$ (Colcol and Baudoin 2016), indicating that QLR isolates were not common, and that the population of 46 to $65 \%$ QLR E. necator isolates in the QLR vineyard is unusual in Virginia. The discriminatory concentration used in our bioassays to identify QLR isolates was lower than the quinoxyfen rate applied in our field trials (97 to $112 \mathrm{mg}$ a.i./liter), but the results of Colcol and Baudoin (2016) showed only very limited dose dependence of QLR powdery mildew inhibition, and $30 \mathrm{mg}$ a.i./liter clearly distinguished QRL isolates from sensitive isolates.

Our 2014 and 2015 field data, as well as the Wilcox and Riegel data cited above, suggested that quinoxyfen tended to perform better in controlling powdery mildew on grape clusters than on leaves. Given that cluster symptoms develop during early stages of berry development while foliar symptoms continue to develop throughout the season, we wanted to test the hypothesis that quinoxyfen is more effective early than late in the season. In 2016, we compared treatments with different quinoxyfen application timing, but differences in disease severity based on the timing of two applications were small and not statistically significant (Table 3). Control of foliar disease incidence by two early applications $(2 \mathrm{QE})$ was significantly better than that by two mid- or late-season applications (2QM and 2QL). Overall, the hypothesis that quinoxyfen works better if applied early found some but only weak support in our 2016 data.

Isolates tolerating high quinoxyfen levels have been documented for other powdery mildew species. The risk of developing resistance to quinoxyfen was first evaluated in $B$. graminis years before the product was commercialized (Hollomon et al. 1997). The baseline $\mathrm{ED}_{50}$ ranged from $<0.001 \mathrm{mg} / \mathrm{liter}$ to $0.16 \mathrm{mg} / \mathrm{liter}$, and median $\mathrm{ED}_{50}$ was between 0.001 and $0.005 \mathrm{mg} / \mathrm{liter}$. Mutants with $\mathrm{ED}_{50}$ values $>0.16 \mathrm{mg} /$ liter (one reported at $>5 \mathrm{mg} / \mathrm{liter}$ ) were isolated at a very low frequency in the field. Mutants were also acquired by chemical treatment in the lab (Hollomon et al. 1997). In 2002, Bernhard et al. (2002) reported sensitivity of wheat powdery mildew against quinoxyfen as monitored from 1995 to 2000 in Western Europe. The mean $\mathrm{EC}_{50}$ ranged from $0.039 \mathrm{mg} / \mathrm{liter}$ to $0.071 \mathrm{mg} / \mathrm{liter}$, showing no shift or adaptation in sensitivity of $B$. graminis at that point (Bernhard et al. 2002). However, isolates with reduced sensitivity were detected in Germany since 2001, 3 years after its commercial introduction in 1998, and in northern France starting in 2003 (Walker et al. 2006). In France, they made up 22 to $36 \%$ and up to $66 \%$ of the population, depending on the region. However, in field trials in most regions, quinoxyfen remained one of most effective fungicides when applied preventatively early in the season, but in the Champagne region efficacy reductions against $B$. graminis were observed, but were variable and not consistent (Walker et al. 2006).

In addition, cucurbit powdery mildew (Podosphaera xanthii) strains that tolerated quinoxyfen at 40 and $80 \mathrm{mg} / \mathrm{liter}$ have been reported from cucurbit fields in New York (McGrath 2013), and more recently, in 2015, isolates that tolerated $200 \mathrm{mg} / \mathrm{liter}$, which is approximately the maximum field rate for the crop (McGrath 2017). However, quinoxyfen was still as effective as the other treatments in the trial plots where the isolates were collected, which was attributed to selection having occurred during that growing season, but not fast enough to affect efficacy. This is not a viable explanation in our grape experiments where the QLR isolates were present throughout three seasons.

It is unclear why quinoxyfen is still able to provide good control of powdery mildew in the field while over $50 \%$ of the isolates present cannot be controlled with field rates on lab-treated leaves or potted plants. Field conditions as such do not appear to harm the isolates as shown by their persistence in the field, but perhaps field conditions (temperature and humidity fluctuations and extremes, UV radiation, etc.) combined with the presence of quinoxyfen may have a harmful effect. Further research is needed to clarify this.

Despite the fact that the type of quinoxyfen resistance described in our report had only a modest effect on the fungicide's efficacy in the vineyard, prudence supports continuing to follow the recommendations to the growers made by FRAC (Kemmitt et al. 2017) and to use quinoxyfen with caution: to apply early in the season, preventatively, before significant disease development occurs; to apply no more than three times per season, with no more than two consecutive applications; to mix quinoxyfen with fungicides of other modes of action; and to closely monitor the efficacy of quinoxyfen and switch to other fungicides when powdery mildew control deteriorates.

\section{Acknowledgments}

We thank Caroline B. Lucernoni, Nicole Flores, Morgan Gallagher, and Heather Rigg for performing bioassays and providing general lab assistance; and Dr. David Haak, Dr. Boris Vinatzer, and Dr. David Schmale for their helpful reviews of this manuscript.

\section{Literature Cited}

Bernhard, U., Leader, A., Longhurst, C., and Felsenstein, F. G. 2002. Quinoxyfenresistance management and sensitivity monitoring in wheat: 1995-2000. Pest Manag. Sci. 58:972-974.

Colcol, J. F., and Baudoin, A. B. 2016. Sensitivity of Erysiphe necator and Plasmopara viticola in Virginia to QoI fungicides, boscalid, quinoxyfen, thiophanate methyl, and mefenoxam. Plant Dis. 100:337-344.

Dhillon, W. S., Bindra, A. S., and Kapoor, S. P. 1992. Some biochemical changes induced in powdery mildew infected grapevine leaves. Plant Dis. Res. 7: 248-250.

Gadoury, D. M., Cadle-Davison, L., Wilcox, W. F., Dry, I. B., Seem, R. C., and Milgroom, M. G. 2012. Grapevine powdery mildew (Erysiphe necator): A fascinating system for the study of the biology, ecology and epidemiology of an obligate biotroph. Mol. Plant Pathol. 13:1-16.

Gadoury, D. M., Wilcox, W. F., Rumbolz, J., and Gubler, W. D. 2015. Powdery mildew. Pages 75-83 in: Compendium of Grape Diseases, Disorders, and Pests, 2nd Ed., W. F. Wilcox, W. D. Gubler, and J. K. Uyemoto, eds. American Phytopathological Society, St Paul, MN. 
Genet, J. L., and Jaworska, G. 2009. Baseline sensitivity to proquinazid in Blumeria graminis f. sp. tritici and Erysiphe necator and cross-resistance with other fungicides. Pest Manag. Sci. 65:878-884.

Green, E., and Duriatti, A. 2005. Sensitivity of Uncinula necator isolates to quinoxyfen: Baseline studies, validation of baseline method, and targeted sensitivity monitoring after several years of commercial use. Pages 163-168 in: BCPC Int. Congr. Crop Sci. Technol. BCPC Publications, Alton, Hampshire GU34 2QD, United Kingdom.

Green, E. A., and Gustafson, G. D. 2006. Sensitivity of Uncinula necator to quinoxyfen: Evaluation of isolates selected using a discriminatory dose screen. Pest Manag. Sci. 62:492-497.

Halleen, F., and Holz, G. 2001. An overview of the biology, epidemiology and control of Uncinula necator (powdery mildew) on grapevine, with reference to South Africa. S. Afr. J. Enol. Vitic. 22:111-121.

Heinze, G., and Schemper, M. 2002. A solution to the problem of separation in logistic regression. Stat. Med. 21:2409-2419.

Hollomon, D. W., Wheeler, I., Dixon, K., Longhurst, C., and Skylakakis, G. 1997. Defining the resistance risk of the new powdery mildew fungicide quinoxyfen. Pestic. Sci. 51:347-351.

Kemmitt, G., Genet, J.-L., Jaworska, G., and Couery, O. 2017. Protocol of the discussions and recommendations of the AZN Working Group of the Fungicide Resistance Action Committee (FRAC). Online publication. http://www.frac.info/docs/default-source/working-groups/azn-fungicides/ group/minutes-of-the-2017-azn-meeting-recommendations-for-2017.pdf.

Kemmitt, G., Genet, J.-L., Szubstarski, P., and Jaworska, G. 2013. Protocol of the discussions and recommendations of the AZN Working Group of the Fungicide Resistance Action Committee (FRAC). Online publication. http://www.frac. info/docs/default-source/working-groups/azn-fungicides/group/minutes-ofthe-2013-azn-meeting-recommendations-for-2014.pdf.

Kemmitt, G., Genet, J.-L., Szubstarski, P., Jaworska, G., Picard, A., and Straebler, B. 2014. Protocol of the discussions and recommendations of the AZN Working Group of the Fungicide Resistance Action Committee (FRAC). Online publication. http://www.frac.info/docs/default-source/working-groups/ azn-fungicides/group/minutes-of-the-2014-azn-meeting-recommendationsfor-2015.pdf.

Lee, S., Gustafson, G., Skamnioti, P., Baloch, R., and Gurr, S. 2008. Host perception and signal transduction studies in wild-type Blumeria graminis f. sp. hordei and a quinoxyfen-resistant mutant implicate quinoxyfen in the inhibition of serine esterase activity. Pest Manag. Sci. 64:544-555.
McGrath, M. T. 2013. Efficacy of fungicides with resistance risk for cucurbit powdery mildew and fungicide sensitivity of Podosphaera xanthii in New York. (Abstr.) Phytopathology 103:S2.93.

McGrath, M. T. 2017. First Report of resistance to quinoxyfen of Podosphaera xanthii, causal agent of cucurbit powdery mildew, in the United States. Plan Health Prog. 18:94.

R Core Team. 2017. R: A language and environment for statistical computing. $\mathrm{R}$ Foundation for Statistical Computing, Vienna, Austria. https://www. R-project.org/.

Stummer, B. E., Francis, I. L., Zanker, T., Lattey, K. A., and Scott, E. S. 2005 Effects of powdery mildew on the sensory properties and composition of Chardonnay juice and wine when grape sugar ripeness is standardised. Aust. J. Grape Wine Res. 11:66-76.

Thind, T. S., Arora, J. K., Mohan, C., and Raj, P. 2004. Epidemiology of powdery mildew, downy mildew and anthracnose diseases of grapevine. Pages 621-638 in: Diseases of Fruits and Vegetables. S. A. M. H. Naqvi, ed. Vol. I. Springer, Netherlands.

Walker, A.-S., Wilhelm, E., and Leroux, P. 2006. Observatoire des resistances aux fongicides chez l'Oidium due ble: resultats du groupe de travail AFPP 20012005. Pages 533-544 in: AFPP - $8^{\text {ème }}$ Conference Internationale sur les Maladies des Plantes, Tours.

Wheeler, I., Hollomon, D., Longhurst, C., and Green, E. 2000. Quinoxyfen signals a stop to infection by powdery mildews. Pages 841-846 in: The BCPC Conference: Pests and diseases, Vol. 3.

Wheeler, I. E., Hollomon, D. W., Gustafson, G., Mitchell, J. C., Longhurst, C., Zhang, Z., and Gurr, S. J. 2003. Quinoxyfen perturbs signal transduction in barley powdery mildew (Blumeria graminis f. sp. hordei). Mol. Plant Pathol. 4:177-186.

Wilcox, W. F., and Riegel, D. G. 2012a. Evaluation of fungicide programs for control of grapevine powdery mildew, 2011. Online publication. Plant Dis Manage. Rep. 6:SMF044. http://www.plantmanagementnetwork.org/pub/trial/ $\mathrm{pdmr} /$ volume6/abstracts/smf044.asp.

Wilcox, W. F., and Riegel, D. G. 2012b. Evaluation of fungicide programs for control of grapevine powdery mildew, 2010. Online publication. Plant Dis. Manage. Rep. 6:SMF048. http://www.plantmanagementnetwork.org/pub/trial/ pdmr/volume6/abstracts/smf048.asp.

Wilcox, W. F., and Riegel, D. G. 2012c. Evaluation of fungicide programs for control of powdery mildew on Chardonnay grapes, 2010. Online publication. Plant Dis. Manage. Rep. 6:SMF049. http://www.plantmanagementnetwork.org/ pub/trial/pdmr/volume6/abstracts/smf049.asp. 